\title{
The Improvement of Natural Science Learning Outcomes about Force through The Multiple Inquiry Learning Model in Vocational School Students in SD Negeri Wero in Academic Year 2018/2019
}

\author{
Maudhi Cinthia Larasati ${ }^{1}$, Ngatman $^{2}$, Ratna Hidayah ${ }^{3}$ \\ 1,2,3 Universitas Sebelas Maret \\ maudhilaras05@gmail.com
}

\section{Article History}

accepted 01/10/2019

\begin{abstract}
This study aimed to improve natural science learning outcomes of fifth grade students of $S D$ Negeri Wero on science subjects about force. This study is a classroom action research (CAR) conducted in three cycles with five meetings. Data sources used were students and teachers. Data used were in the form of qualitative data, namely the application of guided inquiry learning models and quantitative data, namely the test results of learning the subject of science about force. Data collection techniques used in this study included test and non-test techniques. The validity of the data used was techniques of triangulation and data sources. Data analysis was done through data reduction, data presentation, and conclusion drawing. The results of this study indicated that the application of a guided inquiry learning model could improve science learning outcomes about force in fifth grade SD Negeri Wero. The implication of this study is that students are directly involved in the investigation activities during learning so that students get meaningful learning experiences and students become easier to remember the material that has been learned, through the process of formulating problems, actively, and initiatives to find concepts through inquiry with learning models guided inquiry so that students become accustomed to learning critically about the surrounding phenomena, in learning by applying guided inquiry learning models students are involved directly in the learning process so that they can train students to be skilled in obtaining and analyzing information from various learning sources, increasing student enthusiasm during learning through investigative activities, increasing the attitude of cooperation through the process of group discussion, and training students' self-confidence through presentations.
\end{abstract}

Keywords: Guided inquiry, learning outcomes, science

\begin{abstract}
Abstrak
Penelitian ini bertujuan untuk meningkatkan hasil belajar IPA siswa kelas V SD Negeri Wero pada mata pelajaran IPA tentang kekuatan. Penelitian ini adalah penelitian tindakan kelas (PTK) yang dilakukan dalam tiga siklus dengan lima pertemuan. Sumber data yang digunakan adalah siswa dan guru. Data yang digunakan adalah dalam bentuk data kualitatif, yaitu penerapan model pembelajaran inkuiri terbimbing dan data kuantitatif, yaitu hasil tes pembelajaran subjek sains tentang kekuatan. Teknik pengumpulan data yang digunakan dalam penelitian ini meliputi teknik tes dan non-tes. Validitas data yang digunakan adalah teknik triangulasi dan sumber data. Analisis data dilakukan melalui reduksi data, penyajian data, dan penarikan kesimpulan. Hasil penelitian ini menunjukkan bahwa penerapan model pembelajaran inkuiri terbimbing dapat meningkatkan hasil belajar sains tentang kekuatan di kelas lima SD Negeri Wero. Implikasi dari penelitian ini adalah bahwa siswa terlibat langsung dalam kegiatan penyelidikan selama pembelajaran sehingga siswa mendapatkan pengalaman belajar yang bermakna dan siswa menjadi lebih mudah mengingat materi yang telah dipelajari, melalui proses perumusan masalah, secara aktif, dan inisiatif untuk menemukan konsep melalui inkuiri
\end{abstract}


Volume 7 Nomor 3 Tahun 2019

dengan model pembelajaran inkuiri terbimbing sehingga siswa menjadi terbiasa belajar secara kritis tentang fenomena di sekitarnya, dalam pembelajaran dengan menerapkan model pembelajaran inkuiri terbimbing siswa terlibat langsung dalam proses pembelajaran sehingga mereka dapat melatih siswa untuk terampil dalam mendapatkan dan menganalisis informasi dari berbagai sumber belajar, meningkatkan antusiasme siswa selama pembelajaran melalui kegiatan investigasi, meningkatkan sikap kerjasama melalui proses diskusi kelompok, dan melatih kepercayaan diri siswa melalui presentasi.

Kata kunci: Inkuiri terbimbing, hasil belajar, sains 


\section{PENDAHULUAN}

Pendidikan mempunyai peranan penting untuk meningkatkan kualitas masyarakat Indonesia terutama bagi perkembangan bangsa. Oleh karena itu, pendidikan perlu dikembangkan dari berbagai ilmu pengetahuan, karena dengan adanya pendidikan yang berkualitas dapat meningkatkan kecerdasan bangsa. Pedoman penyelenggaraan pembelajaran untuk mencapai tujuan pendidikan diatur dalam kurikulum.

Kurikulum adalah seperangkat rencana dan peraturan mengenai tujuan, isi, dan bahan pelajaran serta cara yang digunakan sebagai pedoman penyelenggaraan kegiatan pembelajaran untuk mencapai tujuan pendidikan. Kurikulum sebagai program pendidikan yang telah direncanakan secara sistematis mengemban peranan yang sangat penting bagi pendidikan para siswa (Hamalik, 1990: 8). Struktur kurikulum merupakan pola dan susunan mata pelajaran yang harus ditempuh oleh peserta didik dalam kegiatan pembelajaran.

Setiap mata pelajaran di sekolah dasar memiliki tujuan yang berbeda-beda, salah satunya ilmu pengetahuan alam (IPA) yang bertujuan mengembangkan keterampilan proses untuk menyelidiki alam sekitar, memecahkan masalah, dan dapat membuat keputusan. Hal ini didukung oleh pendapat dari Susanto (2016: 169) bahwa IPA merupakan kumpulan fakta dan konsep maka IPA membutuhkan proses dalam menemukan fakta dan teori yang akan digeneralisasi oleh ilmuwan.

Berdasarkan wawancara dengan guru kelas dan pengamatan proses pembelajaran yang dilakukan pada hari Sabtu, 3 November 2018 dalam pembelajaran IPA di kelas V SD Negeri Wero diperoleh informasi bahwa pada saat pelaksanaan pembelajaran, guru masih menggunakan model pembelajaran konvensional yaitu pembelajaran tradisional yang ditandai dengan ceramah, penjelasan, pembagian tugas, serta latihan yang mendominasi pembelajaran mengakibatkan (1) respon siswa terhadap materi yang sedang berlangsung masih kurang, terbukti pada saat pembelajaran berlangsung, siswa lebih memilih diam; (2) pembelajaran kurang bermakna, karena siswa tidak diberikan kesempatan untuk menemukan fakta dan konsep sendiri; (3) pembelajaran yang dilaksanakan kurang inovatif sehingga membuat anak-anak bosan dan lebih memilih untuk bercerita dengan temannya; (4) rasa ingin tahu siswa masih rendah, hal ini terlihat saat guru menawarkan untuk bertanya tentang materi yang kurang paham, tidak ada siswa yang bertanya; dan (5) hasil belajar IPA kelas V SD Negeri Wero rendah, pada saat ulangan harian rata-rata nilai 50 serta terdapat $78 \%$ dari 23 siswa yang mendapatkan nilai di bawah KKM yang ditentukan sekolah yaitu 75, karena hasil belajar kognitif IPA kelas V SD Negeri Wero rendah maka peneliti akan melakukan penelitian pada hasil belajar yang difokuskan pada ranah kognitif.

Permasalahan yang ditemukan pada saat observasi menunjukkan hasil belajar IPA masih rendah. Hal tersebut menandakan bahwa adanya permasalahan yang perlu dicari solusi untuk memecahkan permasalahan tersebut. Perlu adanya inovasi terhadap model pembelajaran yang digunakan pada saat pembelajaran untuk meningkatkan pembelajaran IPA sehingga dapat meningkatkan hasil belajar.

Model inkuiri merupakan model yang menempatkan siswa sebagai subjek dalam pembelajaran yang berarti siswa memiliki andil dalam menentukan suasana dan model pembelajaran. Setiap peserta didik didorong untuk terlibat aktif dalam proses belajar mengajar, salah satunya dengan secara aktif mengajukan pertanyaan terhadap materi yang disampaikan. Menurut Anam (2016: 16-17) terdapat empat tingkatan inkuiri, antara lain inkuiri terbimbing yaitu siswa bebas menentukan gaya belajar, namun tetap sesuai dengan bimbingan dari guru.

Hal ini didukung oleh pendapat Piaget model pembelajaran inkuiri terbimbing merupakan model yang tepat untuk mempersiapkan siswa melakukan eksperimen sehingga siswa melihat secara langsung apa yang terjadi, melakukan secara langsung, 
mengajukan pertanyaan-pertanyaan, mencari jawabannya sendiri, serta menghubungkan penemuan yang satu dengan penemuan yang lain, dan membandingkan sesuatu yang ditemukannya dengan yang ditemukan siswa lain (Mulyasa, 2009: 109). Hal ini didukung oleh pendapat dari Susanto (2016: 172) pembelajaran inkuiri menekankan pada semua pendidik agar menerapkan kegiatan pembelajaran yang menekankan pada proses dalam pemahaman materi pelajaran.

Peneliti melakukan penelitian tindakan kelas dengan menerapkan langkahlangkah model pembelajaran inkuiri terbimbing yaitu: (1) orientasi; (2) merumuskan masalah; (3) mengajukan hipotesis; (4) mengumpulkan data; (5) menguji hipotesis; (6) merumuskan kesimpulan. Penerapan model pembelajaran inkuiri terbimbing diharapkan mampu mengajak siswa untuk aktif dan terlibat di dalam proses pemecahan masalah dalam pembelajaran maka dapat menghasilkan pembelajaran yang bermakna bagi siswa dan tepat digunakan untuk meningkatkan hasil belajar siswa kelas V. Hal ini sesuai dengan penelitian yang dilakukan oleh Syam, Sukma, dan Laili (2016) yang membuktikan pada penelitiannya bahwa terdapat pengaruh yang positif antara inkuiri terbimbing (guided inquiry) terhadap hasil belajar siswa, karena model pembelajaran inkuiri terbimbing dapat mengembangkan cara berpikir ilmiah yang menempatkan siswa dapat memecahkan masalah dan memperoleh pengetahuan berupa penyelidikan sehingga dapat memahami konsep IPA. Matthew dan Kenneth (2013) yang membuktikan pada penelitiannya bahwa siswa yang mengikuti pembelajaran dengan menggunakan model inkuiri terbimbing dituntut untuk dapat memecahkan permasalahan secara langsung sehingga siswa mendapatkan prestasi yang lebih baik dibandingkan dengan siswa yang mengikuti pembelajaran konvensional.

Rumusan masalah dalam penelitian ini adalah: (1) Bagaimana penerapan model pembelajaran inkuiri terbimbing dalam peningkatan hasil belajar kognitif IPA tentang gaya di kelas V SD Negeri Wero tahun ajaran 2018/2019?; (2) Apakah penerapan model pembelajaran inkuiri terbimbing dapat meningkatkan hasil belajar kognitif pada pembelajaran IPA tentang gaya di kelas V SD Negeri Wero tahun ajaran 2018/2019?; (3) Apakah kendala dan solusi pada penerapan model pembelajaran inkuiri terbimbing dalam peningkatan hasil belajar kognitif IPA tentang gaya di kelas $\mathrm{V}$ SD Negeri Wero tahun ajaran 2018/2019?

Tujuan dari penelitian ini adalah: (1) Mendeskripsikan penerapan model pembelajaran inkuiri terbimbing dalam peningkatan hasil belajar kognitif IPA tentang gaya di kelas V SD Negeri Wero tahun ajaran 2018/2019; (2) Meningkatkan hasil belajar kognitif IPA tentang gaya di kelas V SD Negeri Wero tahun ajaran 2018/2019 dengan penerapan model pembelajaran inkuiri terbimbing; (3) Mendeskripsikan kendala dan solusi pada penerapan model pembelajaran inkuiri terbimbing dalam peningkatan hasil belajar kognitif IPA tentang gaya di kelas V SD Negeri Wero tahun ajaran 2018/2019.

\section{METODE}

Penelitian ini dilaksanakan di SD Negeri Wero, Desa Wero, Kecamatan Gombong, Kabupaten Kebumen, Provinsi Jawa Tengah. SD Negeri wero memiliki letak yang sangat strategis yaitu beralamat di Jalan Yos Sudarso Timur No. 576 Wero, Gombong, dan bersebrangan dengan Puskesmas Gombong I yang berada di jalan raya Gombong-Kebumen.

Penelitian ini adalah penelitian tindakan kelas kolaboratif, subjek penelitian dalam penelitian ini adalah siswa kelas V SD Negeri Wero yang berjumlah 23 siswa serta guru kelas V. Data yang digunakan adalah data kualitatif dan data kuantitatif, data kualitatif berupa penerapan model pembelajaran inkuiri terbimbing, sedangkan data kuantitatif berupa hasil belajar IPA tentang gaya. Sumber data yang digunakan adalah siswa kelas $\mathrm{V}$ dan guru kelas $\mathrm{V}$. Teknik pengumpulan data yang digunakan ada 
dua, yaitu teknik tes dan nontes. Alat pengumpulan data dengan menggunakan lembar observasi dan pedoman wawancara. Validitas data dalam penelitian ini adalah triangulasi teknik dan sumber data. Analisis data yang digunakan ada tiga, yaitu reduksi data, penyajian data, dan penarikan kesimpulan.

Prosedur penelitian menurut Arikunto (2013: 137) terdiri dari empat tahap yaitu perencanaan, pelaksanaan, observasi, dan refleksi. Setiap siklus dalam PTK selalu berhubungan dan berkelanjutan, apabila siklus I belum mencapai target, maka dilakukan perbaikan pada siklus selanjutnya melalui analisis masalah dan refleksi. Pelaksanaan penelitian dilaksanakan selama tiga siklus dengan lima pertemuan.

Gambaran dari model PTK menurut Arikunto (2013: 137) sebagai berikut:

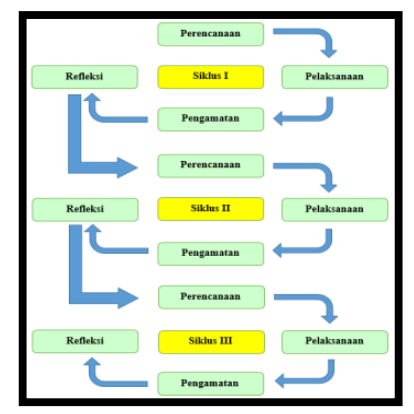

Gambar 1. Alur Penelitian Tindakan Kelas (Modifikasi)

(Sumber : Arikunto, 2013: 137)

\section{HASIL DAN PEMBAHASAN}

Peneltian ini dilaksanakan dengan 3 siklus. Siklus I dua pertemuan, siklus II dua pertemuan dan siklus III satu pertemuan. tiap-tiap siklus dilaksanakan berdasarkan RPP yang pelaksanaannya yaitu: (1) pada kegiatan pendahuluan yang dilakukan guru adalah membuka pelajaran, berdoa, menanyakan kabar, memberikan apersepsi, menyampaikan tujuan, dan motivasi, (2) pada kegiatan inti guru menjelaskan materi menggunakan langkah-langkah inkuiri terbimbing yaitu orientasi, merumuskan masalah, mengajukan hipotesis, mengumpulkan data, menguji hipotesis, dan merumuskan kesimpulan (3) kegiatan penutup dilakukan dengan menyimpulkan kegiatan pembelajaran dari awal hingga akhir, mengerjakan soal evaluasi, dan berdoa bersama.

Penerapan langkah-langkah inkuiri terbimbing pada siklus I sudah cukup baik, namun masih terdapat kekurangan yang harus diperbaiki pada siklus selanjutnya. Hal ini dibuktikan dengan adanya observasi, wawancara, hasil belajar, dan kendala sehingga peneliti melanjutkan ke siklus II. Pada siklus II mengalami peningkatan pada penerapan model pembelajaran inkuiri terbimbing walaupun belum mencapai target indikator kinerja $85 \%$. Selanjutnya peneliti melanjutkan ke siklus III. Pada siklus III persentase pada penerapan langkah-langkah model pembelajaran inkuiri terbimbing sudah mencapai target yang ditentukan sehingga peneliti mengakhiri penelitian. Data observasi selama penelitian terdapat pada tabel 1. 


\begin{tabular}{lllll}
\hline & & \multicolumn{3}{c}{ Siklus } \\
\cline { 3 - 5 } & & I & II & III \\
\hline Guru & $\begin{array}{l}\text { Persentase } \\
(\%)\end{array}$ & 79,12 & 84,75 & 90,50 \\
Siswa & $\begin{array}{l}\text { Persentase } \\
(\%)\end{array}$ & 70,50 & 83,50 & 89,50 \\
\hline
\end{tabular}

Berdasarkan tabel 1 dapat diketahui bahwa hasil observasi mengenai penerapan model pembelajaran inkuiri terbimbing yang dilaksanakan oleh guru pada siklus I memiliki persentase $79,12 \%$, siklus II $84,75 \%$. Antara siklus I dan siklus II terjadi peningkatan sebesar $5,63 \%$. Siklus III meningkat $5,75 \%$ menjadi $90,50 \%$. Hasil observasi terhadap siswa pada siklus I memiliki persentase $70,50 \%$, siklus II $83,50 \%$. Antara siklus I dan siklus II terjadi peningkatan $13 \%$. Siklus III meningkat $6 \%$ menjadi $89,50 \%$. Dapat disimpulkan bahwa setiap siklus selalu mengalami peningkatan.

Selain hasil observasi, berikut peningkatan hasil belajar siswa dengan menggunakan langkah-langkah model pembelajaran inkuiri terbimbing pada siklus I, II, III pada tabel 2.

\begin{tabular}{lccc}
\hline & Siklus I & Siklus II & Siklus III \\
\hline Tuntas & 80,43 & 89,12 & 95,65 \\
Belum & 19,57 & 10,86 & 4,34 \\
Tuntas & & & \\
\hline
\end{tabular}

Berdasarkan tabel 2 dapat diketahui bahwa hasil observasi mengenai hasil belajar IPA melalui model pembelajaran inkuiri terbimbing pada siklus I memiliki persentase siswa yang tuntas 80,43\%, siklus II 89,12\%, siklus III 95,65\%. Dapat disimpulkan bahwa hasil belajar siswa setiap siklus meningkat.

Penelitian ini dilaksanakan dalam 3 siklus, siklus I dan II terdiri dari 2 pertemuan, siklus III terdiri dari 1 pertemuan. Penerapan model pembelajaran inkuiri terbimbing dengan langkah-langkah yang meliputi: a) orientasi; b) merumuskan masalah; c) mengajukan hipotesis; d) mengumpulkan data; e) menguji hipotesis; dan f) merumuskan kesimpulan. Langkah tesebut sesuai dengan pendapat dari Sanjaya (2012: 201). Pembelajaran dengan menerapkan model pembelajaran inkuiri terbimbing terbukti dapat meningkatkan pembelajaran.

Langkah pertama inkuiri terbimbing yaitu orientasi, siswa mengamati fenomena atau demonstrasi terkait dengan topik pembelajaran, agar siswa dapat membangun pemahaman tentang suatu konsep yang dialami secara langsung berdasarkan pengalaman (Agustini, 2016). Hal ini didukung dengan pendapat Bundu (2006: 88) siswa melakukan pengamatan terhadap fenomena menggunakan panca indera maka informasi yang didapatkan akan mendorong rasa ingin tahu siswa.

Langkah kedua inkuiri terbimbing yaitu merumuskan masalah, siswa dilibatkan dalam penyampaian permasalahan yang terkait dengan materi. Siswa membuat pertanyaan yang kemudian akan disusun menjadi rumusan masalah dan jika rumusan masalah sudah sesuai dengan indikator maka guru mengkondisikan siswa untuk berdiskusi. Hal ini didukung oleh pendapat Samatowa (2016: 67) ketika siswa 
mengajukan pertanyaan, merumuskan pertanyaan, serta menemukan jawaban dengan adanya penyelidikan dapat menjadikan siswa aktif dalam pembelajaran.

Langkah ketiga inkuiri terbimbing yaitu mengajukan hipotesis, siswa bersama dengan guru menjawab pertanyaan yang ditentukan pada tahap merumuskan masalah, kemudian hasil hipotesis akan dicocokkan dengan hasil penyelidikan. Hal ini didukung dengan pendapat Samatowa (2016: 101) bahwa seseorang mengajukan hipotesis untuk menjelaskan kejadian sesuai dengan pengetahuan awal.

Langkah keempat inkuiri terbimbing yaitu mengumpulkan data, siswa diberikan pengalaman langsung dengan kegiatan penyelidikan. Hal tersebut sesuai dengan pendapat Piaget bahwa inkuri merupakan pembelajaran dengan melibatkan siswa untuk melakukan percobaan sendiri agar siswa dapat mengalami dan melihat secara langsung, mengajukan pertanyaan, mencari jawaban sendiri, menghubungkan, dan membandingkan hasil penemuannya dengan penemuan siswa lain (Mulyasa, 2009: 108). Data yang diperoleh pada proses pengumpulan data menjadi sumber informasi dalam proses pembuktian hipotesis, hal ini sesuai dengan penelitian dari Putri, Indrawati, dan Mahardika (2016: 323) yang menyatakan bahwa dalam model pembelajaran inkuiri terbimbing siswa dibimbing untuk mengumpulkan dan menganalisis data guna pembuktian hipotesis.

Langkah kelima inkuiri terbimbing yaitu membuktikan hipotesis, siswa berdiskusi dengan kelompok untuk membahas hasil penelitian dan menguji hipotesis, apakah hipotesis tersebut ditolak atau diterima. Menguji hipotesis harus didukung dengan data yang dapat dipertanggungjawabkan, karena hipotesis dapat mengembangkan kemampuan berpikir rasional siswa (Sanjaya, 2013: 202).

Langkah keenam inkuiri terbimbing yaitu merumuskan kesimpulan, siswa menarik kesimpulan hasil penyelidikan. Pada langkah ini siswa mempresentasikan hasil diskusi sehingga dapat meningkatkan kemampuan komunikasi siswa (Wisudawati dan Sulistyowati, 2014: 115).

Terdapat enam langkah model pembelajaran inkuiri terbimbing yaitu orientasi, merumuskan masalah, mengajukan hipotesis, mengumpulkan data, membuktikan hipotesis, dan merumuskan kesimpulan. Dari keenam langkah model pembelajaran inkuiri terbimbing yang sudah diterapkan dalam pembelajaran, siswa terlihat senang dan antusias pada saat pelaksanaan langkah keempat yaitu mengumpulkan data, pada langkah ini siswa diberikan pengalaman langsung dengan kegiatan penyelidikan tentang materi gaya.

Berdasarkan hasil analisis terhadap peningkatan hasil belajar siswa setelah dilaksanakan tindakan dapat dibuktikan bahwa penerapan model pembelajaran inkuiri terbimbing dapat meningkatkan hasil belajar IPA tentang gaya. Hal tersebut sesuai dengan tujuan dari pendidikan IPA di SD yang berorientasi pada hasil belajar (Bundu, 2006: 18). Selanjutnya hal tersebut juga diperkuat dengan penelitian yang dilaksanakan oleh Sriyanti (2015) yang membuktikan bahwa model pembelajaran inkuiri terbimbing dapat meningkatkan hasil belajar siswa.

Peningkatan hasil belajar IPA tentang gaya melalui model pembelajaran inkuiri terbimbing pada siswa kelas V SD Negeri Wero tahun ajaran 2018/2019 mengalami kendala saat proses pelaksanaan tindakan selama siklus I, II, dan III, kendala tersebut meliputi: a) siswa kurang aktif karena guru kurang memberikan motivasi kepada siswa; b) siswa masih bingung saat membuat hipotesis dikarenakan guru belum menguasai cara untuk mengarahkan siswa membuat hipotesis; c) siswa terlihat kebingungan saat menggunakan alat dan bahan dikarenakan guru tidak membimbing siswa dalam menggunakan alat bahan untuk percobaan; d) guru kurang menguasai langkahlangkah model pembelajaran inkuiri terbimbing; e) siswa belum terbiasa dengan model pembelajaran inkuiri terbimbing; f) hanya siswa pandai yang terlibat dalam pembelajaran; g) beberapa siswa tidak konsentrasi dan masih memilih untuk bermain dengan temannya saat pembelajaran; h) beberapa siswa tidak konsentrasi dalam 
mengikuti pembelajaran karena bermain-main dengan alat dan bahan untuk penyelidikan; i) beberapa siswa tidak memperhatikan kelompok yang sedang mempresentasikan hasil diskusi di depan kelas karena asik bermain dengan temannya; dan j) pembelajaran melebihi waktu yang ditentukan karena guru kurang cermat dalam membagi waktu dalam pembelajaran; dan k) beberapa siswa pasif saat mengikuti pembelajaran karena merasa tidak percaya diri.

$\mathrm{Hal}$ ini didukung oleh pendapat Sanjaya (2012: 208-209) bahwa SPI memiliki kekurangan antara lain pembelajaran memerlukan waktu yang panjang, serta pendapat Sujarwo (2011: 96-97) bahwa inkuiri terbimbing memiliki kekurangan antara lain pembelajaran hanya melibatkan siswa yang aktif dan beberapa siswa kurang memiliki kesadaran menyelesaikan tugasnya.

Berdasarkan kendala-kendala yang ditemui dalam pelaksanaan tindakan penelitian pada siklus I, II, dan III, maka peneliti menawarkan solusi sebagai berikut: a) berdiskusi dengan guru untuk memotivasi siswa agar lebih aktif dalam pembelajaran; b) berdiskusi bersama dengan guru tentang penguasaan model pembelajaran inkuiri terbimbing; c) guru membimbing siswa dengan menggunakan alat bahan untuk percobaan sesuai dengan langkah-langkah; d) meningkatkan wawasan guru tentang model pembelajaran inkuiri terbimbing; e) meningkatkan bimbingan siswa dalam pembelajaran; $\quad$ f) memberikan tugas kepada masing-masing siswa dan memberikan hadiah kepada siswa yang aktif; g) memberikan nasehat kepada siswa yang tidak konsentrasi pada saat pembelajaran; $h$ ) menegur siswa yang bermain pada saat pembelajaran; i) memusatkan perhatian siswa ke depan kelas ketika ada kelompok yang sedang presentasi; j) guru harus lebih cermat dalam membagi waktu dalam pembelajaran; dan k) pemberian motivasi agar semangat dalam mengikuti pembelajaran dan mendapatkan hasil belajar yang baik.

\section{SIMPULAN}

Berdasarkan hasil penelitian dan pembahasan yang telah diuraikan maka simpulan dari penelitian ini adalah:

1. Peningkatan hasil belajar IPA tentang gaya melalui model pembelajaran inkuiri terbimbing pada siswa kelas V SD Negeri Wero tahun ajaran 2018/2019 dilaksanakan dengan langkah-langkah yaitu: a) orientasi; b) merumuskan masalah; c) mengajukan hipotesis; d) mengumpulkan data; e) menguji hipotesis; dan f) merumuskan kesimpulan.

2. Penerapan model pembelajaran inkuiri terbimbing dapat meningkatkan hasil belajar IPA tentang gaya pada siswa kelas V SD Negeri Wero tahun ajaran 2018/2019. Hasil belajar siswa selalu meningkat di setiap siklus, hal ini dibuktikan dengan perolehan persentase setiap siklus. Siklus I $80,43 \%$, siklus II $89,12 \%$, dan siklus III $95,65 \%$. Penelitian sudah mencapai target indikator kinerja penelitian yang ditentukan yaitu $85 \%$.

3. Kendala pada peningkatan hasil belajar IPA tentang gaya melalui model pembelajaran inkuiri terbimbing pada siswa kelas V SD Negeri Wero tahun ajaran 2018/2019 yaitu: a) siswa tertentu mendominasi kegiatan pembelajaran sehingga kurangnya kesempatan bagi siswa yang lain untuk belajar secara maksimal; b) pembelajaran memerlukan waktu yang lama; c) hanya terlihat siswa tertentu saja yang aktif saat pembelajaran, karena beberapa siswa kurang memiliki kesadaran dan usaha dalam menyelesaikan tugas kelompok. Adapun solusi yang dilaksanakan oleh guru yaitu: a) guru memberikan motivasi supaya siswa aktif dalam mengikuti pembelajaran serta memberikan kesempatan terbuka kepada siswa untuk aktif dengan menunjuk salah satu siswa atau kelompok; b) guru lebih cermat dalam menggunakan waktu pembelajaran dengan cara memfokuskan pada kegiatan yang sesuai dengan skenario pembelajaran; dan c) guru membagi tugas kepada siswa 
dalam kelompok agar semua siswa berperan aktif dalam menyelesaikan tugas kelompok sesuai peran.

\section{DAFTAR PUSTAKA}

Agustini, N. P. S. (2016). Penerapan Model Inkuiri Terbimbing Berbantuan Media Konkret untuk Meningkatkan Sikap Ilmiah dan Hasil Belajar IPA Siswa Kelas V. E-Jurnal PGSD Universitas Pendidikan Ganesha, 4 (1), 1-10.

Anam, K. (2016). Pembelajaran Berbasis Inkuiri: Metode dan Aplikasi. Yogyakarta: Pustaka Pelajar.

Arikunto, S. (2013). Prosedur Penelitian: Suatu Pendekatan Praktik. Jakarta: Rineka Cipta.

Bundu, P. (2006). Penilaian Ketrampilan Proses dan Sikap Ilmiah dalam Pembelajaran Sains di Sekolah Dasar. Jakarta: Departemen Pendidikan Nasional.

Hamalik, O. (1990). Pengembangan Kurikulum Dasar-dasar dan Perkembangannya. Bandung: Mandar Maju.

Matthew, B. M. dan Kenneth I. O. (2013). A Study on The Effect of Guided Inquiry Teaching Method On Students Achievement In Logic. International Research, 2 (1), 135-140.

Mulyasa, E. (2009). Menjadi Guru Profesional: Menciptakan Pembelajaran Kreatif dan Menyenangkan. Bandung: Remaja Rosdakarya.

Putri, H. K., Indrawati, dan Mahardika, I. K. (2016). Model Pembelajaran Inkuiri Terbimbing disertai Teknik Peta Konsep dalam Pembelajaran Fisika di SMA. Jurnal Pembelajaran Fisika, 4 (4), 321-326.

Samatowa, U. (2016). Pembelajaran IPA di Sekolah Dasar. Jakarta: PT Indeks.

Sanjaya, W. (2012). Strategi Pembelajaran Berorientasi Standar Proses Pendidikan. Jakarta: Kencana Prenadamedia Group.

Sanjaya, W. (2013). Strategi Pembelajaran: Implementasi Standar Proses Pendidikan. Jakarta: Kencana Pramedia Group.

Sriyanti. (2015). Peningkatan Aktivitas dan Hasil Belajar Siswa Melalui Metode Inkuiri Terbimbing di Kelas V SD Negeri Terbahsari. Skripsi Tidak Dipublikasikan. Universitas Negeri Yogyakarta.

Sujarwo. (2011). Model-Model Pembelajaran: Suatu Strategi Mengajar. Yogyakarta: Venus Gold Press.

Susanto, A. (2016). Teori Belajar dan Pembelajaran di Sekolah Dasar. Jakarta: Kencana Prenadamedia Group.

Syam, M., Sukma, dan Laili, K. (2016). Pengaruh Model Pembelajaran Inkuiri Terbimbing (Guided Inquiry) Dan Motivasi Terhadap Hasil Belajar Fisika Siswa. Jurnal Saintifika, 18 (1), 59-63.

Wisudawati, A. W. \& Sulistyowati, E. (2014). Metodologi Pembelajaran IPA. Jakarta: Bumi Aksara. 